\title{
STUDY OF CRYOPROTECTORAL PROPERTIES OF FOOD FIBERS IN THE COMPOSITION OF MEAT PHARMACEUTICALS SYSTEMS
}

\author{
O. Skochko, I. Kyshenko \\ National University of Food Technologies
}

\begin{tabular}{|c|c|}
\hline Key words: & ABSTRACT \\
\hline $\begin{array}{l}\text { Food fibers } \\
\text { Cryoprotectants } \\
\text { Meat stuffing systems } \\
\text { Deep freezing } \\
\text { Water activity }\end{array}$ & \multirow{3}{*}{$\begin{array}{l}\text { As new and emerging nutritional claims appear on the } \\
\text { market, understanding of the functionality of these ingre- } \\
\text { dients is especially important, as there are no standard reco- } \\
\text { mmendations for their use. The article presents the results of } \\
\text { studying the functional and technological properties of } \\
\text { dietary fiber of plantain in comparison with wheat fiber for } \\
\text { using in the technology of deep-frozen and long-term stored } \\
\text { semifinished products. The mechanism of cryoprotective } \\
\text { action of dietary fibers in meat forages systems involves the } \\
\text { formation of an amorphous structure in the middle of the } \\
\text { product, with decrease of number of crystallization centers } \\
\text { and decrease of water activity, which positively affects on } \\
\text { the preservation of the dense structure of semi-finished } \\
\text { products after } 30 \text { days of storage in the frozen state and } \\
\text { promotes obtaining high quality products. }\end{array}$} \\
\hline \begin{tabular}{l}
\multicolumn{1}{c}{ Article history: } \\
Received 07.11.2017 \\
Received in revised form \\
24.11 .2017 \\
Accepted 22.12 .2017
\end{tabular} & \\
\hline $\begin{array}{l}\text { Corresponding author: } \\
\text { O. Skochko } \\
\text { E-mail: } \\
\text { npnuht@ukr.net }\end{array}$ & \\
\hline
\end{tabular}

DOI: $10.24263 / 2225-2924-2017-23-6-22$

\section{ВИВЧЕННЯ КРІОПРОТЕКТОРНИХ ВЛАСТИВОСТЕЙ ХАРЧОВИХ ВОЛОКОН У СКЛАДІ М'ЯСНИХ ФАРШЕВИХ СИСТЕМ}

\section{O.I. Скочко, I.I. Кишенько}

Національний університет харчових технологій

Оскільки на ринку з'являються все нові і нові пропозиції харчових волокон, особливо важливим є розуміння функціональних можливостей иих інгредієнтів, тому що стандартних рекомендаиій щодо їх використання не існує. У статті наведено результати вивчення функиіонально-технологічних властивості харчових волокон подорожника порівняно з пшеничною клітковиною з метою використання в технології посічених напівфабрикатів глибокого заморожування і тривалого зберігання. Механізм кріопротекторної дії харчових волокон у м'ясних фаршевих системах пов'язаний з утворенням аморфної структури всередині продукту і зменшенням кількості иентрів кристалізацї̈ та зі зниженням активності води, щчо позитивно впливає на 
збереження щільної структуру напівфабрикатів після 30 діб зберігання 8 замороженому стані і сприяє отриманню продуктів високої якості.

Ключові слова: харчові волокна, кріопротектори, м'ясні фаршеві системи, глибоке заморожування, активність води.

Постановка проблеми. Відсутність будь-якого термічного і хімічного оброблення робить спосіб кріоконсервування екологічно-безпечним способом, що абсолютно не погіршує біохімічні властивості та чистоту харчових продуктів. Інтенсивність і характер змін м'яса та м'ясних продуктів при заморожуванні залежить від умов і параметрів процесу, а також від якісних характеристик сировини. Специфіка складу й будови м'ясної сировини, особливості та взаємозв'язок фізико-хімічних і біохімічних процесів, що відбуваються в ній, суттєво впливають на збереження властивостей м'яса i м'ясних напівфабрикатів при заморожуванні.

$\mathrm{y}$ той же час під час заморожування, 3 через пошкодження клітинних мембран порушується баланс окисно-відновних процесів у бік окиснювальних реакцій. Незважаючи на підтверджену ефективність, навіть дуже швидке заморожування м'ясної сировини і м'ясних напівфабрикатів без додавання речовин кріопротекторної дії може призвести до незворотних структурнофункціональних змін клітинної й тканинної структур системи. Водночас процес розморожування супроводжується не тільки втратою вологи, але разом 3 нею й поживних речовин. Тому сучасне виробництво заморожених м'ясних напівфабрикатів потребує розроблення наукових підходів і методів кріозахисту м'ясних фаршевих систем від впливу низьких температур.

Проте кріопротектори, які сьогодні використовуються у харчовій промисловості, не здатні ефективно зв'язати вологу у м'ясних фаршевих системах 3 підвищеним вологовмістом і зниженим вмістом жиру. Водночас підбір кріопротекторів для різних м'ясних систем необхідно здійснювати окремо, залежно від їх складу та функціонально-технологічних властивостей.

Мета статті: дослідити кріопротекторні властивості пшеничної клітковини як найбільш поширеної на ринку України та клітковини подорожника, використання яких дасть змогу знизити кріоскопічну температуру і запобігатиме суттєвому кристалоутворенню та уповільненню перебігу процесу заморожування.

Методи і обладнання. При визначенні органолептичних, фізико-хімічних показників модельних фаршевих м'ясних систем використовували стандартні методи досліджень.

Структурно-механічні показники визначали на пенетрометрі Ulab3-31M. Пенітрацію посічених навіфабрикатів визначали за глибиною занурення індентора у дослідний зразок за температури $20^{\circ} \mathrm{C}$. Проводили три вимірювання на відкритій поверхні зразка на відстані не менше 10 мм від краю виробу і на максимальній відстані від точок інших вимірювань, щоб деформована частина поверхні не увійшла в зону вимірювання, після чого проводили перерахунок значення пенетрації у значення пенетраційної напруги. 
Показник активності води $a_{w}$ модельних фаршевих систем та м'ясних посічених напівфабрикатів визначали за допомогою аналізатора rotronic Hygro Palm-23.

Вимірювання кріоскопічної температури модельних фаршевих систем i м'ясних посічених напівфабрикатів проводили методом термічного аналізу, що базується на побудові кривих зміни температури у часі.

Обидва види клітковини додавали до складу модельних фаршевих систем, виготовлених на основі односортної яловичини (50\%) та напівжирної свинини $(50 \%)$, та здійснювали часткову заміну основної сировини на ізоляти харчових волокон. За контроль було обрано м'ясну фаршеву систему без вмісту харчових волокон. Отримані зразки фаршу піддавали перемішуванню за температури $12^{\circ} \mathrm{C}$ протягом $15 \mathrm{xв}$, формували у вигляді котлет і заморожували за температури мінус $18^{\circ} \mathrm{C}$. Тривалість зберігання за зазначеної температури становила 30 діб. У всіх зразках до заморожування, після розморожування й термічного оброблення визначали органолептичні, фізико-хімічні, функціонально-технологічні, структурно-механічні показники, а також показник активності води $a_{w}$ та значення кріоскопічної температури.

Результати і обговорення. Середньостатистичні дані результатів досліджень властивостей модельних м'ясних фаршів 3 додаванням харчових волокон замість рівноцінної частки нежирної основної сировини (яловичини) представлено в табл. 1 та 2. Аналіз даних табл. 1 та 2 дає змогу стверджувати, що для всіх зразків м'ясних модельних систем, які містять харчові волокна, характерні загальні тенденції зміни функціонально-технологічних властивостей.

Табличя 1. Функціонально-технологічні і структурно-механічні властивості модельних фаршів із рослинною клітковиною $(n=3, P=0,95)$

\begin{tabular}{|c|c|c|c|c|c|c|c|c|}
\hline \multirow{2}{*}{\begin{tabular}{|c|} 
Кіль- \\
кість \\
Клітко- \\
вини, \\
\% \\
\end{tabular}} & \multicolumn{2}{|c|}{$\begin{array}{c}\text { Показник } \\
\mathrm{pH}\end{array}$} & \multicolumn{2}{|c|}{$\begin{array}{c}\text { Вологозв'язуюча } \\
\text { здатність, \% }\end{array}$} & \multicolumn{2}{|c|}{$\begin{array}{c}\text { Пластичність, } \\
\text { смI/г }\end{array}$} & \multicolumn{2}{|c|}{\begin{tabular}{|c|} 
Граничне напру-ження \\
зсуву, Па \\
\end{tabular}} \\
\hline & $\begin{array}{c}\text { пшени- } \\
\text { чна }\end{array}$ & $\begin{array}{c}\text { подорож- } \\
\text { ника }\end{array}$ & $\begin{array}{c}\text { пшени- } \\
\text { чна }\end{array}$ & $\begin{array}{c}\text { подорож- } \\
\text { ника }\end{array}$ & $\begin{array}{c}\text { пшени- } \\
\text { чна }\end{array}$ & $\begin{array}{c}\text { подорож- } \\
\text { ника }\end{array}$ & пшенична & $\begin{array}{c}\text { подорож- } \\
\text { ника }\end{array}$ \\
\hline 0 & 5,8 & 5,8 & 51,9 & 5 & 6,0 & 6,0 & 1069,25 & 1069,11 \\
\hline 1 & 5,9 & 6,0 & 56,9 & 71 & 6,1 & 6,9 & 1061,30 & 1058,15 \\
\hline 2 & 5,9 & 6,1 & 61,3 & 72,8 & 6,2 & 7,0 & 1053,12 & 1049,57 \\
\hline 3 & 5,9 & 6,1 & 60,6 & 74,8 & 6,2 . & 7,0 & 1052,12 & 1046,12 \\
\hline
\end{tabular}

Таблиия 2. Функціонально-технологічні властивості термооброблених модельних фаршів із рослинною клітковиною після 30 діб зберігання за температури мінус $18^{\circ} \mathrm{C}$ $(n=3, P=0,95)$

\begin{tabular}{|c|c|c|c|c|c|c|c|c|}
\hline $\begin{array}{c}\text { Кіль- } \\
\text { кість } \\
\text { клітк-- }\end{array}$ & \multicolumn{2}{|c|}{$\begin{array}{c}\text { Вихід, \% } \\
\text { вини, } \\
\%\end{array}$} & $\begin{array}{c}\text { Вологоутримуюча } \\
\text { здатність, \% до } \\
\text { загальної вологи }\end{array}$ & \multicolumn{2}{|c|}{$\begin{array}{c}\text { Пластичність, } \\
\mathrm{cm}^{2} / \Gamma\end{array}$} & $\begin{array}{c}\text { Граничне напруження } \\
\text { зсуву, Па }\end{array}$ \\
\hline 0 & 65,3 & 65,7 & 48,7 & 48,7 & 5,1 & 5,7 & 4556,82 & 5049,11 \\
\hline 1 & 68,4 & 70,6 & 62,8 & 74,1 & 5,1 & 5,8 & 6516,30 & 78054,15 \\
\hline 2 & 70,8 & 74,8 & 66,5 & 76,7 & 5,2 & 5,9 & 7463,12 & 8969,57 \\
\hline 3 & 70,6 & 74,9 & 66,2 & 78,4 & $5,3$. & 5,9 & 7539,9 & 9326,12 \\
\hline
\end{tabular}


До заморожування та після термічного оброблення, порівняно $з$ контрольними зразками, збільшується вологозв'язуюча здатність (В33) у м'ясних системах, які містять $2 \%$ пшеничної клітковини та клітковини подорожника на 9,4\% та 20,9\% відповідно, та вологоутримуюча здатність (ВУз) - на 17,8\% та $28,8 \%$ відповідно. Показники граничного напруження зсуву (ГНЗ) при збільшенні вмісту харчових волокон зменшуються, а після термічного оброблення зростають. Ймовірно, це пояснюється тим, що у контрольному зразку при заморожуванні та подальшому термічному обробленні втрачається більша кількість вологи, змінюється конформація білків, унаслідок чого система стає більш жорсткою. М'ясні модельні фаршеві системи, що містять харчові волокна, внаслідок кращого зв'язування ними вологи мають, відповідно, більш ніжну консистенцією [1;2].

Важливим технологічним показником $є$ вихід продукту. Визначення втрат при термічному обробленні модельних фаршів показало, що більший вихід мають усі розроблені зразки за рахунок використання харчових волокон, а найкращий вихід мають зразки з використанням $2 \%$ харчових волокон подорожника. Збільшення виходу дослідних зразків можна пояснити кращим утриманням у процесі нагрівання мобілізованої вологи за рахунок капілярного ефекту властивому харчовим волокнам [1-3].

Відомо, що чим менше вологи в продукті, тим нижча початкова кріоскопічна температура. Зв'язок між кількістю вимороженої води й температурою зберігання залежить також від вмісту вологи в м'ясі, оскільки він впливає на склад тканинного соку та його розподіл. Отже, кількість вимороженої води слід вважати функцією температури, складу та структури продукту, а тому додавання харчових волокон у м'ясні фаршеві системи приводить до зменшення кількості вимороженої вологи (табл. 3).

Таблиця 3. Втрати маси термооброблених модельних фаршів 3 рослинною клітковиною $(n=3, P=0,95)$

\begin{tabular}{|c|c|c|c|c|c|c|c|c|}
\hline \multirow{2}{*}{$\begin{array}{c}\text { Втрати маси, \% } \\
\text { під час }\end{array}$} & \multicolumn{7}{|c|}{ Вміст клітковини, \% } \\
\cline { 2 - 10 } & \multicolumn{2}{|c|}{0} & \multicolumn{2}{|c|}{1} & \multicolumn{2}{|c|}{3} \\
\cline { 2 - 9 } & $\begin{array}{c}\text { пше- } \\
\text { нична }\end{array}$ & $\begin{array}{c}\text { подо- } \\
\text { рожника }\end{array}$ & $\begin{array}{c}\text { пше- } \\
\text { нична }\end{array}$ & $\begin{array}{c}\text { подо- } \\
\text { рожника }\end{array}$ & $\begin{array}{l}\text { пше- } \\
\text { нична }\end{array}$ & $\begin{array}{c}\text { подо- } \\
\text { рожника }\end{array}$ & $\begin{array}{c}\text { пше- } \\
\text { нична }\end{array}$ & $\begin{array}{c}\text { подо- } \\
\text { рожника }\end{array}$ \\
\hline $\begin{array}{c}\text { теплового оброблення до } \\
\text { заморожування }\end{array}$ & 29,3 & 29,3 & 26,2 & 25,1 & 23,1 & 22,3 & 24,0 & 22,1 \\
\hline заморожування & 2,6 & 2,6 & 2,1 & 2,0 & 1,9 & 1,7 & 1,9 & 1,7 \\
\hline $\begin{array}{c}\text { теплового оброблення } \\
\text { після заморожування }\end{array}$ & 33,6 & 33,4 & 29,4 & 27,9 & 25,8 & 24,5 & 26,6 & 24,2 \\
\hline
\end{tabular}

Аналіз результатів дослідження масової частки вимороженої води у модельних м'ясних фаршевих системах свідчить, що найбільшу масову частку вимороженої вологи має контрольний зразок - 2,6\%. Далі їі частка зменшується зі збільшенням кількості доданої клітковини: 3 додаванням пшеничних волокон на $1,9 \%$, клітковини подорожника $-1,7 \%$.

Вода в м'ясних системах є середовищем для активного перебігу процесів біохімічного псування і тому консервуюча дія заморожування направлена на 
зниженні активності води $a_{w}$. При малих значеннях активності води волога більш зв'язана у м'ясних системах і тому менш доступна для перебігу хімічних реакцій та розвитку мікроорганізмів, що сприяє подовженню терміну їх зберігання [1; 4-7].

Внесення вищезазначених речовин як кріопротекторів у модельні фаршеві системи позитивно вплинуло і на зниження показника активності води $a_{w}$ на $0,027-0,033$ при використанні пшеничної клітковини та на $0,027-0,036-$ при використанні клітковини подорожника, після 30 діб зберігання.

Зниження активності води в дослідних зразках можна пояснити підвищенням концентрації розчинних речовин у м'ясному соку, що обумовило зниження температури початку кристалізації вологи у м'ясних фаршевих системах i, відповідно, зміну характеру зростання кристалів льоду в клітинній структурі м'язової тканини [4-6].

Значення кріоскопічної температури для дослідних зразків становило: для контрольного $-\left(-2,75^{\circ} \mathrm{C}\right)$, для зразка № $1-\left(-3,84^{\circ} \mathrm{C}\right)$, для зразка № $2-$ $\left(-4,56^{\circ} \mathrm{C}\right)$.

При заморожуванні, зберіганні, розморожуванні й термічному обробленні у посічених напівфабрикатах спостерігалось незначне зниження величини $\mathrm{pH}$ на $0,02-0,04$ відносно початкового рівня $\mathrm{pH}$ унаслідок розпаду глікогену, що залишився у м'ясі до заморожування й утворення молочної кислоти.

Серед усіх дослідних зразків термооброблених м'ясних фаршевих систем найбільші зміни органолептичних показників якості (після заморожування, зберігання протягом 30 діб і розморожування) спостерігались у контрольних зразках, що характеризувалися недостатньою соковитістю, крихкістю структури, меншим виходом і більш високими на 2,9-3,1\% втратами при термооброблені. Проте дослідні зразки мали підвищену соковитість і більш щільну консистенцію.

Слід зазначити, що при збільшенні кількості внесення харчових волокон більше $2 \%$ спостерігається зниження функціольно-технологічних показників м'ясних фаршевих систем, хоча вони залишаються на досить високому рівні, що необхідно враховувати при їх практичному застосуванні.

\section{Висновки}

Отримані результати підтверджують доцільність використання харчових волокон у кількості $2 \%$ як речовин, дії яких направлених на кріозахист м'ясних фаршевих систем від впливу низьких температур.

Завдяки своїм гідрофільним властивостям пшенична клітковина та клітковина подорожника здатні знизити шкідливий вплив фізико-хімічних факторів і захистити м'ясні системи від деструкції клітин при кріоконсервуванні.

\section{Література}

1. Рогов И.А. Химия пищи. Кн. 1 (Белки: структура, функции, роль в питании) / И.А. Рогов. - Москва : КолосС, 2007. - 853 с.

2. Салаватулина Р.М. Рациональное использование сырья в колбасном производстве / P.М. Салаватулина. - Санкт-Петербург : ЗАО Торговый дом Георд, 2005. - 236 с. 
3. Фейнер Г. Мясные продукты. Научные основы, технологии, практические рекомендации / Г. Фейнер; пер. с англ. Н.В. Магды. - Санкт-Петербург : Профессия, 2010. - 720 с.

5. Кишенько I.I. Оцінка впливу речовин кріопротекторної дії на показники якості посічених напівфабрикатів / I.I. Кишенько, О.І. Скачко// Харчова промисловість. — 2017. № 21. - С. $89-94$.

6. Куцакова В.Е. Холодильная технология пищевых продуктов. Часть III. Биохимические и физико-химические основы / В.Е. Куцакова, А.В. Бараненко, Т.Е. Бурова, М.И. Кременевская. - Санкт-Петербург : ГИОРД, 2011. - 272 с.

7. Сязин И.Е., Касьянов Г.И. Феномен криообработки продуктов. - Монография. Саарбрюккен, Германия : Palmarium Academic Publishing, 2012. — 296 c.

8. Касьянов Г.И. Инновационные технологии криообработки сельскохозяйственного сырья: монография / Г.И. Касьянов, О.И. Квасенков, И.Е. Сязин., А.В. Кочерга. - Краснодар : Изд. ФГБОУ ВПО «КубГТУ», 2013. - 147 с. 